\title{
NFKBID Gene
}

National Cancer Institute

\section{Source}

National Cancer Institute. NFKBID Gene. NCI Thesaurus. Code C150060.

This gene may be involved in the regulation of nuclear factor-kappa-B activity and cytokine gene expression. 